\title{
In memoriam: Reinhard Hujer
}

It is with great sadness that we share the news of the death of Prof. Dr. Reinhard Hujer, who passed away on 13 August 2020 at the age of 79. From 1995 to 2013, Reinhard Hujer was, with a short interruption, a member of the Editorial Board of the Journal for Labour Market Research (formerly known as: Zeitschrift für ArbeitsmarktForschung), and temporarily also its Executive Publisher. His major interests encompassed economic and social science-related panel studies, application of appropriate statistical and econometric methods in labour market research, and evaluation of the effects of active labour market policies. His scientific excellence in these areas found its manifestation not least in numerous respective publications in internationally renowned journals. His experience, expertise and a great many suggestions were always of great value to the journal.

Reinhard Hujer was not only a committed editor and an outstanding scientist, he was a person of incredible kindness and wit. He will be sadly missed. Our deepest sympathies and thoughts go to his family.

The Editors.
Published online: 29 September 2020

\section{Publisher's Note}

Springer Nature remains neutral with regard to jurisdictional claims in published maps and institutional affiliations. 